\title{
ANALYSIS OF AUDIT REPORT LAG ON SERBIAN STOCK EXCHANGE
}

\author{
Ana Obradović, \\ Vule Mizdraković, \\ Goran Avlijaš
}

Singidunum University, Belgrade, Serbia

\begin{abstract}
:
In this paper, the audit report lag for Serbian business entities listed on Belgrade Stock Exchange will be analysed and the results will be compared with other countries. Auditors perform the control of financial statements, and methods and documentation used for financial reporting preparation, which ultimately increases their reliability. Having that in mind, keeping track of the audit reports delivery dates has become a matter of interest in everyday business and investors' decision-making process. In this paper a random sample of 196 public companies from the Republic of Serbia has been used to provide a descriptive statistic on Audit Report Lag (ARL). Also, a comparative analysis of related research from other countries has been done. Results show that minimum number of ARL in Serbia was 30 and a maximum number of days is 355. Also, the results show that ARL values for the audits performed by Big 4 auditors are higher than for the audits performed by the other audit companies.
\end{abstract}

Keywords:

audit reports, comparative analysis, Big Four, public companies
Correspondence:

Ana Obradović

e-mail:

aobradovic@singidunum.ac.rs

\section{INTRODUCTION}

Auditing is used to verify the faithfulness of the financial reports and to raise the level of their reliability. This is an instrument to reduce the risk of using incorrect or unreliable information by main stakeholders. The aim of audit reports for the auditor is to disclose the opinion if the financial reports are prepared in accordance with the professional legislation, i.e. the adequate financial reporting framework. By conducting audit services, the auditor provides a high level of assurance that the information contained in the financial reports does not contain materially significant unreliable amounts. In most cases, when the users are forming their own opinion, they rely on the auditor opinion. The audit opinion is very important additional information for investors, which they use when they make about future investments. Investors generally expect ARL to be as short as possible so that they can make investment decisions in time.

Financial reporting for public companies is very important for a healthy growth of financial markets. Therefore, it is crucial that their financial reports are of high quality. Also, investors should base their business decision-making process on an independent auditor opinion, which is provided in accordance with the Code of ethics for professional accountants. Large and medium business entities, public companies, parent companies for consolidated financial reports, as well as all legal entities and entrepreneurs whose revenues in the previous financial reports exceeded 4,400,000 euros have the legal obligation of performing mandatory audit (Knezevic, Stanisic \& Mizdrakovic, 2017). 
Entities mentioned above have an obligation to perform an audit and deliver the audit report to the Serbian Business Registers Agency. Those opinions, together with the audited financial reports are available to the public. The remaining entities (micro and small-sized entities) can perform an audit on a voluntary basis. According to the Law on Accounting, audits are obligatory for public companies whose stocks are sold on the domestic market, foreign market or OTC (Over the Counter) market. It is important to mention that neither the Law on Accounting, nor the Law on Capital Market does not pose the minimal request regarding the type of auditor opinion that public companies must have. However, in developed countries and financial markets, it is required for public companies to have an unqualified opinion in order to remain on the stock exchange.

An audit represents a significant part of the financial reports analysis and the assessment of company's success. One of the aspects that are relevant are the days of delivering the audit reports (Audit Report Lag), which will be analysed in this paper. An increase in the number of days that pass between the date of the end of financial reporting period and the delivery date of the audit report can lead to a decrease in investors' trust. It is expected that the investors will wait for the audit reports to be disclosed before they decide whether to invest in a company. Therefore, it can be said that ARL represents a significant factor in the economy of a country. Also, higher ARL can suggest that audit company had to perform more audit activities which in turn means that quality of financial reports is probably lower. Audit report lag, as it has been stated, has a great impact on the investors' trust and it helps in the growth of the financial markets and the economy as a whole. This has been the subject of many papers and research in the previous thirty years. Usually, authors conclude that late delivery of audit reports did in fact have an impact on their credibility.

As already mentioned, audit reports are delivered to the Business Registers Agency together with the financial reports. The deadline for the delivery of the report is June $30^{\text {th }}$ of the current year for the financial statements of the previous reporting period. For consolidated reports the deadline is July $31^{\text {st }}$. According to the Law on Accounting, Article 24, the company chooses the audit company until September $30^{\text {th }}$ of the current business year for which the audit is to be performed. When it comes to the consolidated financial reports the time limit may vary and it could be longer. If the calendar year does not match the business year, the deadline is three months before the end of that business year. Audit report lag is calculated by comparing financial reporting date, December 31th, and theaudit report date. The difference shows the number of days known as ARL.

\section{LITERATURE REVIEW}

According to (Geiger \& Raghunandan, 2002) the audit report is the final outcome of the audit process, and is the only external communication of what the auditor has done and concluded during the audit. In addition to the analysis of the number of days of the ARL, it is important to look out for the possible causes that affect it. Previous research shows that there are different determinants which effect ARL:

- audit tenure,

- auditor opinion type,

- Big 4/non-Big 4 auditor,

- auditor change,

- business industry,

- auditors' industry specialization,

- auditor client's net income,

- auditor client's size,

- listed or over the counter auditor client,

- auditor client's age, and

- the probability of bankruptcy of auditor client.

Audit tenure shows the number of years an auditor is engaged by the client-firm (Lee, Mande \& Son, 2009). According to the same authors, auditors with long tenure are able to audit their clients more efficiently. Previous research shows that companies with an unqualified audit opinion have shorter ARL than companies with other types of audit opinion (Walker \& Hay, 2013). Also, there are differences in audit report lag depending on which audit company performed the audit - companies which belong to Big Four and non-Big Four audit companies. Previous research shows that the ARL for Big Four clients was shorter than ARL for clients of other audit companies (Schwartz \& Soo, 1996).

Past research shows that an auditor change can affect ARL. When an auditor has a client for several years, he/ she becomes familiar with clients business and structure of their assets. However, when a different auditor is appointed, that change could result in an increase of audit costs for the client company and affect the length of the ARL (Schwartz \& Soo, 1996). Namely, it takes more time for the newly appointed auditor to complete audit, therefore ARL should be longer.

When it comes to business industry, according to Ashton, Willingham \& Elliot (1987)financial companies have shorter audit delays than companies in other industries. That can be explained by the fact that financial companies have a low level of fixed assets and highly centralized and automated accounting systems (Schwartz \& Soo, 1996). Non-financial companies like Oil and gas industry, Transportation and Real estate and construction have longer ARL in comparison to the financial companies for 
almost a month(Ashton, Graul \& Newton, 1989).Auditors' industry specialization has an impact on the ARL, as well. According to Habiba \& Bhuiyanb (2011), industry specialist auditors have specific knowledge as an advantage and they will be able to resolve complex accounting issues and transactions in a less number of days than non-specialist auditors. This leads to the conclusion that ARL will be shorter when the audit is being performed by industry specialist auditors, because of their strong industry-focused knowledge.

The profitability of an audit client calculated as net income or the net result could have an influence on ARL, as well. Auditor clients with negative net income have longer ARL than companies reporting zero or positive net income. Results show that there is a difference in a range of one week up to a month between these entities (Ashton, Graul \& Newton, 1989). This comes as no surprise, as business entities that have unprofitable business will more likely engage in false financial reporting, or white and black creative accounting. Therefore, auditing risk will be higher and the auditor will have to perform more auditing operations in order to decrease the risk to acceptable level in order to provide an opinion.

There is a connection between the ARL and the risk of audit work, if certain events are to happen and it is necessary for the auditor to do some extra work in certain areas (Bamber, Bamber \& Schoderbek, 1993). Also, some of the authors set the hypotheses about the possible causes of the ARL on an examined sample. One of their assumptions, based on the previous research, was that the size of audit client affects the ARL. The results have shown that there is a connection between these two variables. The same conclusions were drawn from the analysis of the impact an audit company has on performing the audit itself. Here a categorization has been made - whether the audit company belongs to the Big Four ${ }^{1}$ or not (Walker \& Hay, 2013). In the mentioned paper, this variable affects the ARL.

On the other hand, there is an opinion that the ARL depends precisely on the audit-specific issues, as well as the audit fees or audit hours, type of auditors, the uncertainty of opinion in the audit report (Leventis, Weetman $\&$ Caramanis, 2005). Results of conducted research (Bamber, Bamber \& Schoderbek, 1993) provided the evidence that the structured audit approach is associated with a longer ARL.

The financial position has an impact on longer audit delay, as well. Past research results point out that in regard to the impact of the company's financial condition on audit delays, financially weak companies can be expected to be associated with longer audit delays (Bamber, Bamber \& Schoderbek, 1993). Also, companies that had a longer period of the ARL had bigger losses at that time (Courtis,

1 Refers to Deloitte, KPMG, Ernst \& Young, PricewaterhouseCoopers
1976), (Carslaw \& Kaplan, 1991). When it comes to the type of auditor opinion there is a connection between them and ARL. Whittred's study found that companies receiving qualified audit opinions were associated with longer audit delays (Whittred, 1980).

In the research by Mohamed-Nor, Shafie \& Wan-Hussein (2010), the sample included 856 companies which stocks were listed on the Malaysian market in 2002. A certain number of companies did not fulfill the conditions in terms of availability of the necessary reports, and 628 companies have been selected as the sample for research. Past research about subjects on the Malaysian market shows that the number of days was longer, just like it was mentioned. When compared, the ARL was shorter for approximately two weeks. The complete sample has been divided into four categories based on the length of the ARL. Two-thirds of the sample have submitted the audit reports in the fourth month after the end of the fiscal year (Mohamed-Nor, Shafie \& Wan-Hussein, 2010).

When it comes to companies that perform business operations on the Hong Kong market and their audit report lag, the sample included 393 companies, after dismissing the inadequate samples based on the necessary variables, for the period from 1991 till 1993 (Jaggi \& Tsui, 2012). The sample for New Zealand contains a two-year analysis of the ARL (Walker \& Hay, 2013). The final sample included 130 companies, which would be 260 samples of audit reports in a two-year period. The relevance was put on the number of days from the end of the fiscal year until the date on the audit report.

According to the research from 1993, it is stated that the average audit report lag in Malaysia was 116, whereas in 2002, author's sample showeda reduction to only 100 days (Mohamed-Nor, Shafie \& Wan-Hussein, 2010). By applying the statistical models, the variables and the degree of their influence on the ARL have been examined.

\section{RESEARCH METHODOLOGY AND RESULTS}

For the purpose of this paper (research) 196 companies whose stocks are listed on the Belgrade stock exchange were randomly chosen. There were 375 public companies at the moment when the research has been conducted. Therefore, the sample represents $52 \%$ of all public entities. Their audit reports for financial statements from 2015 reporting period have been collected from the Serbian Business Register Agency. The ARL has been calculated for each report and it has been noted if the audit has been performed by one of the Big 4 audit companies.

It has been noticed that the median is 118 days, and that the average audit lag is close to this number, which indicates a possible normal range of values within this set. Research results show that the Big 4 performed audits for 
43 out of 196 sampled entities (22\%). The average ARL for those entities was 122.51 days, the median was 166 days, a minimum number of days was 54 , and 355 the maximum number of days. For 153 companies, the audit reports were done by audit companies which do not belong to the Big 4. For this part of the sample, the average number of days was 116.04, the median was 107 days, the minimum number of days was 31 , and the maximum number of days was the same as for the companies examined in the first part.

The results mentioned above show a few findings. First, the audit which was performed by one of the Big 4 audit companies has a much lowerminimum number of days of ARL than the audits performed by other audit companies. It can be presumed that the reason for these results could be the thoroughness of the procedures performed by Big 4 companies. The second reason could be the size of the client entities, since probably larger sized companies would hire these auditors. However, the maximum number of ARL days was the same.

It should be taken into account that comparative analysis, which was presented in this paper, includes different periods. In comparison to the other countries that were analysed, Serbia has the biggest deviation in a maximum number of days of ARL. According to the Table number one, maximum number of days for Serbia was 355 while Egypt had 115 days as the lowest maximum number of ARL days (Afify, 2009). The maximum number of days of ARL in Serbia resulted in an increase in the average number of days of ARL. Namely, the average number of ARL in Serbia is the highest in comparison to the other countries and equals to 117.46 days. The lowest average number of ARL is in New Zealand, close to two months.

Table 1. Comparative analysis of audit report lag

\begin{tabular}{|c|c|c|c|c|c|c|c|}
\hline & Serbia & Greece & Malayasia & Egypt & $\begin{array}{l}\text { New } \\
\text { Zealand }\end{array}$ & $\begin{array}{l}\text { Hong } \\
\text { Kong }\end{array}$ & Bahrain \\
\hline Year: & 2015 & 2000 & 2002 & 2009 & 2005 & 1993 & 2006 \\
\hline Sample: & 196 & 171 & 628 & 85 & 260 & 393 & 231 \\
\hline $\begin{array}{l}\text { Minimum number of } \\
\text { days: }\end{array}$ & 30 & 30 & 13 & 19 & 21 & 40 & 7 \\
\hline $\begin{array}{l}\text { Maximum number of } \\
\text { days: }\end{array}$ & 355 & 158 & 332 & 115 & 151 & 190 & 154 \\
\hline $\begin{array}{l}\text { Average number of } \\
\text { days: }\end{array}$ & 117.46 & 98 & 100.3 & 67 & 55 & 105 & 48 \\
\hline
\end{tabular}

When it comes to a minimum number of ARL, it takes only one week in Bahrain to report and almost two weeks for auditors in Malaysia (Jasim, 2008). In Serbia, the shortest period of time in which auditor clients could expect to receive auditor report is one month. The same minimum number of ARL has Greece, as the only country analysed from Europe. In this country, all audit companies have to prepare audit reports within 160 days (Leventis, Weetman \& Caramanis, 2005). As it can be noticed, all auditors comply with this regulation. On the other hand, in Serbia all auditors and audit companies have to prepare audit reports within 180 days. A significant number of sampled auditors breached this regulation and disclosed audit report after that period, in some cases a year after.

\section{CONCLUSION}

Instability in the terms of business conditioned by external factors has brought to the re-examining of financial reports and audit reports. There was a need for controlling and increasing the audit report credibility. As it has been noted in this paper, one of the most significant factors of contemporary financial markets is the ARL. The conducted research that has been presented in this paper included a comparison of five markets, together with the market of the Republic of Serbia. The results of the research have shown differences in time periods and the factors that affect the ARL. By comparing the results, it is perceivable that the Republic of Serbia, based on all three criteria, has the longest ARL. Speaking of a minimum number of days, it can be said that it is not far from the average of other countries. The maximum number of days seems to be the problem. In addition to that, an important criterion is the sample collecting time. It could be conducted that there is a connection between the length of ARL and audit company which performed an audit. Results show that companies which audit was performed by Big Four audit companies have longer ARL in Serbia, comparing to the 
audit performed by non-Big four companies. The research results for other markets have been done in the previous ten to twenty years, whereas for the market of the Republic of Serbia the research has been conducted in 2015. The expectations and assumptions are that significant changes occurred in other markets in view of the shortening the ARL period. The limiting factor of the research is also the one-year period for the market of the Republic of Serbia, and in view of that, further analysis should be based on a longer time period, as well as on the establishing variables of great impact on the ARL period. Establishing a shorter ARL should provide greater reliability of audit reports and more confidence from the stakeholders.

\section{LITERATURE}

Afify, H.A.E. (2009). "Determinants of audit report lag Does implementing corporate governance have any impact? Empirical evidence from Egypt".Journal of Applied Accounting Research Vol. 10 No. 1.

Ashton, R.H. Willingham, J.J. Elliott, R.K. (1987). “An empirical analysis of audit delay".Journal of Accounting Research, 275-292.

Ashton, R.H. Graul, P.R. Newton, J.D. (1989) "Audit delay and the timeliness of corporate reporting". Contemporary Accounting Research, 5(2), 657-673.

Bamber, E.M.Bamber, L.S. Schoderbek, M.P. (1993). “Audit structure and other determinants of audit report lag: An empirical analysis". Auditing: Journal of Practice and Theory, 12(1), 1-23.

Carslaw, C.A. Kaplan, S.E. (1991). "An examination of audit delay: Further evidence from New Zealand”.Accounting and Business Research, 22, 21-32.

Courtis, J.K. (1976). "Relationships between timeliness in corporate reporting and corporate attribute".Accounting and Business Research, 6(25),45-56.
Geiger, A.M. Raghunandan, K. (2002). "Auditor Tenure and Audit Reporting Failures”. A Journal of Practice \& Theory Vol. 21, No.1.

Habiba, A. Bhuiyanb, B.U. (2011). "Audit firm industry specialization and the audit report lag".Journal of International Accounting, Auditing and Taxation 20, 32-44.

Jaggi, B.Tsui, J. (2012). “Determinants of audit report lag: further evidence from Hong Kong". Accounting and Business Research.

Jasim, A.A.(2008). "Audit and reporting delays: Evidence from an emerging market, Advances in Accounting". Incorporating Advances in International Accounting 24, 217-226.

Knežević, G.Stanišić, N.Mizdraković, V. (2017). Financial Statement Analysis. University Singidunum.

Lee, H.Y. Mande, V. Son, M. (2009). ”Do Lengthy Auditor Tenure and the Provision of Non-Audit Services by the External Auditor Reduce Audit Report Lags?".International Journal of Auditing 13, 87-104.

Leventis, S. Weetman, P. Caramanis, C. (2005). “Determinants of audit report lag:Some evidence from the Athens Stock Exchange". International Journal of Auditing, 9(1), 4558.

Mohamed-Nor, M.N. Shafie, R. Wan-Hussein, W.N. (2010). "Corporate governance and audit report lag in Malaysia".Asian Academy of management journal of Accounting and Finance, Vol6 No2, 60 - 71.

Schwartz, K.B. Soo, B.S.(1996). "The Association Between Auditor Changes and Reporting Lags".Contemporary Accounting Research Vol.13 No,l, 353-370.

Walker, A. Hay, D. (2013). „Non-Audit Services and Knowledge Spillovers: An Investigation of the Audit Report Lag".Meditari: Accountancy Research, 21(1),32-51.

Whittred, G. (1980)."Audit qualification and the timeliness of client earnings announcements".Accounting Review, 563-577. 